UDC: (371:004):811.111'255.4 https://doi.org/10.22190/JTESAP2003215L

\title{
ESP ONLINE COURSE AS A MEANS OF ENHANCING GRADUATE STUDENTS' EMPLOYABILITY OPPORTUNITIES - CASE OF SUMY STATE UNIVERSITY
}

\author{
Iryna Liashenko, Lyudmyla Hnapovska
}

Sumy State University, Ukraine

E-mail: i.liashenko@uabs.sumdu.edu.ua,1.hnapovska@uabs.sumdu.edu.ua

\begin{abstract}
Along with providing plentiful job market opportunities, the ongoing growth of various technologies in a wide range of fields is currently creating a high level of graduates competitiveness. The issue of employability, which is the crucial concern of higher education institutions, is getting vital these days among employers, educators, researchers, and future professionals. This study aims to determine the mechanisms through which an ESP distance course can facilitate employability enhancement with graduate students. Although the idea of implementing distance learning in the professional training is not new, coherent research on how to make online tasks more enriching for future professional activity and thus resulting in enhanced employability has not been proposed so far. A survey conducted within the framework of the study reveals a correlation between critical thinking skills tasks as part of an ESP course and growing professional competence as an integrated component of employability. The data obtained have been verified by statistical analysis. Another investment in the employability field has been made through suggestions on how to design online tasks properly.
\end{abstract}

Key words: employability, graduate students, online course, ESP, distance learning, blended education

\section{INTRODUCTION}

The issues of employability have been gaining momentum these days as the core task facing the modern market demands. Today's technologies are developing rapidly to let the educators apply all possible techniques in increasing the graduates personal and professional potential in the labor market. Although some researchers have paid due attention to the importance of developing employability in higher education (McQuaid et al. 2005; Lowden et al. 2011), the aspect of raising the motivation to the professional activity remains a debatable research issue (Smith 2010; Ehiyazaryan 2009). Furthermore, many courses taught at universities involve a lot of supplementary activities, which makes students deficient in being fully engaged in all tutorials: e.g. sports students may miss considerable part of their university contact classes attending their meets and participating in sports competitions (Fallows et al. 2000; Butcher and Rose-Adams 2015). The importance of blended education is nowadays overgrowing at universities as a successful means of organizing the learning process for those students who lack possibilities to attend classes

Submitted August $11^{\text {th }}, 2020$, accepted for publication September $9^{\text {th }}, 2020$ 
regularly (Liashenko and Hnapovska 2019; Liashenko 2019). In this case, online learning appears to be an essential educational tool that has to be encouraging in professional issues as it mostly lacks live communication (Lim et al. 2011; Nenzhelele 2014). That is, the main task of modern educators is to find the mechanisms which make online learning more enriching to the labor market requirements.

Against this background, the purpose of this research is to answer the research question: What are the mechanisms that make it possible for an online course of contributing to developing graduate students employability? More specifically, this research has two objectives:

- to define the main features of employability in online training;

- to explore the correlation between the specific professional course and employability growth.

This paper has four parts. First, it reviews the extant literature relevant to the concept of employability and how it can be influenced by online education, which is followed by a description of the research methods and procedures used in the study. The results of our analysis are then discussed. Finally, implications, limitations, and directions for future research are highlighted.

\section{THEORETICAL FRAME}

Employability is known as a central tenet of the labor approach in professional training which plays a vital role in informing the current labor market and training policies (McQuaid et al. 2005) The modern broad, holistic model of employability has been argued as consisting of three main interrelated components that influence a person's employability:

- individual factors covering employability skills and attributes, demographic characteristics, health and wellbeing, job seeking, adaptability, and mobility;

- personal circumstances which include household circumstances, work culture and access to resources;

- external factors, which are demand and enabling support factors. (McQuaid et al. 2005)

These components are possibly influenced by different circumstances, which can be efficiently used in forming employability patterns.

A metaphorical model of employability suggests a correlation of the following interrelated components which lead to employability through reflection and evaluation including self-efficacy, self-confidence, and self-esteem: Career Development Learning, Experience (Work \& Life), Degree (Subject, Knowledge, Understanding \& Skills), Generic Skills, Emotional Intelligence (Pool et al. 2007). This model covers the principal constituents, which are possible to be measured and developed in the classroom setting.

The primary skills the employers consider as the influential factors of successful employability are requirements to the graduates to have good communication skills for expressing themselves persuasively; 'soft' skills, mainly team working which is thought to be even more critical than most 'hard' skills; and professional work abroad (Andrews and Higson 2008). The higher-order skills like critical/creative thinking and problemsolving along with self-management, efficient collaboration, and conscious engagement in the core organization process are stated as the leading factors in getting the job as well 
as the specific learning related to the professional situation (Lowden et al. 2011; Rebenko et al. 2019).

In other words, employability skills are interchangeable essential skills of the $21^{\text {st }}$ century, which are crucial for career success at the workplace in spheres (Overtoom 2000). According to Smith, one of the ways of increasing employability is through identity work, which develops a culture of the personality, such as "...the linguistic aptitude, norms for the presentation of self, and interactional styles that are specific to different occupational and professional environments" (Smith 2010). Another way of enhancing employability is training and networking. Many different types of self-development strategies as a guarantee of successful employment, training, and professional development outside the company, as employees are responsible for network development and training (Smith 2010). It performs the reasons to support the graduates in the educational process in the higher institutions while teaching them the related subjects.

We suggest that the students should obtain professional education, which is the most relevant to real-life situations and which will enable them to perform efficiently in the authentic professional setting. We state that reflective practice is one of the bridges, which has also found its justification in modern research (Ehiyazaryan and Barraclough 2009.) The two factors that may impact employability development are employability development opportunities and experience as well as extracurricular activities, which mostly related to the graduate, as they affect the graduate's ability to be applied (Harvey 2001). In addition to increasing the level of employability, there must be a critical reflection on the skills essential for the workplace (Deeley 2014). We argue that critical thinking increases the level of professional self-acceptance and conscious engagement in professional development.

Work-based learning, along with work-integrated learning experience, results in developing employability in the academic environment at universities, which requires more integrative, cooperative, and action pedagogy to obtain better results (Franz 2008). The experience of transformative and integrative work-based learning should play the leading role in increasing professional motivation and therefore employability.

Listed below are some of the interpersonal 'soft' competencies considered to be integrative to graduate employability (Andrews and Higson 2008):

- Professionalism

- Reliability

- The ability to cope with uncertainty

- The ability to work under pressure

- The ability to plan and think strategically

- The capability to communicate and interact with others, either in teams or through networking

- Good written and verbal communication skills

- Information and Communication Technology skills

- Creativity and self-confidence

- Good self-management and time-management skills.

The relationship between work and study seems to be essential within the framework of work-based learning with a sustained connection to the specific professional environment.

Employability can be influenced by learning. The most basic employability variable skills are communication and team working. Higher educational institutions have been the most suitable places for developing the skills and personal attributes as the components of employability (Tymon 2013). As modern education offers ongoing development of form and 
methods, educators should always bear in mind the specificity of the applied courses and their connection with the professional motivation, which correlates with employability.

Employability skills are suggested to be a set of necessary key skills or attributes related to required activity from an employer, so that is connected to the specific skills within the subject, sector, company, or other specific requirements (Harvey 2001). The role of selfawareness is increasingly becoming one of the leading issues in self-perceived employability (Qenani et al. 2014; Lim et al. 2011). This quality may show how mature the future professional is and their ability to organize the work. Employability is directly connected with competency development. Moreover, competency development is positively related to selfperceived employability (De Vos et al. 2011).

The alarming number of students state that distance learning has a lack of employability component, which is more defined to gain while learning at full-time study at university (Butcher and Rose-Adams 2015). When designing the distance course, the educators should take into account this issue and permeate the studying with the vital element of employability. We approve the methods of acquiring employability skills through the distance learning described in modern research, where the results show a positive correlation between the marital status and employability skills, such as written communication, ability to work in teams, problem-solving skills, numeracy skills, and management skills (Nenzhelele 2014; Botha et al. 2015). It proves that maturity and selfdirectedness towards employability are mostly inherent in self-determined graduates and professionals, who have enough motivation to attain the proper professional level.

Another point to keep to the discussed topic is the fact that IT technologies are constantly developing, which enables a wide range of modern technologies exploits. The specificity of the graduate students is that they are often engaged in part-time work, the sports students may be participating in the competitions, therefore, they may miss the classes. In this case, blended or distance learning seems to be the most suitable pattern for them to take. Thus, our task is to provide students with an efficient education course for developing their professional activity and motivation, as well as the necessary skills for the successful completion of the future job.

Based on the aforementioned discussion, it is hypothesized that the properly designed online course for specific purposes will impact the growth and development of the important skills in employability, particularly, in our research, we assume that raising the amount of critical thinking in an online course will likely develop professional competency.

$\mathrm{H}_{0}: \mu_{\text {critical thinking }}=\mu_{\text {professional competency }}$

$\mathrm{H}_{1}: \mu_{\text {critical thinking }} \neq \mu_{\text {professional competency, where critical thinking covers all relevant }}$ variables and professional competency, is considered as any or some of the constituents according to the theoretical background.

Critical thinking and professional competency constituents will be assessed using a questionnaire, which is the evaluation of the English for Specific Purposes course design to be distributed among the university graduate students of Sports and Finance Faculties.

The study was conducted by means of an online questionnaire distributed amongst a convenience sample of graduate students at Sumy State University, Sports and Finance Faculties. The study was presented as research on the professional impact of critical thinking tasks used in an online ESP course. The development of professional competency was manipulated by randomly assigning participants to a condition where they had a short 8 -hour online course within blended learning. The course for the students was designed 
according to their professional needs. The students' perception of professional competency and critical thinking were assessed using the sum score on a questionnaire consisting of sixteen items that are indicative of professional course design, each rated on a 5-point Likert scale. Participants were debriefed about the real purpose of the study after completing the questionnaire. Participants in the experimental condition who complete the online ESP course with critical thinking tasks are expected to have a significant congruency with professional competency development, which will lead to a more defined level of employability.

\section{METHODS}

In order to explore the objectives of the study, we applied the descriptive survey research. Aimed to collect research data, we applied the survey to analyze the situation with developing professional qualities and which factors stated in our survey might influence them. The data obtained were analyzed by means of statistical methods using software IBM ${ }^{\mathrm{TM}}$ SPSS ${ }^{\mathrm{TM}}$ Statistics (Version 26) software, namely descriptive statistics, and one-way ANOVA analysis.

\subsection{Setting and participants}

The target group for this study consisted of 30 graduate students of mixed faculties (Sports and Finance) who had taken their studies in the fall term of the 2018/2019 academic year. The choice of graduate students is explained by the fact that these students are mostly self-assured at this time and are consciously interested in getting prepared for their future job. Moreover, part of the students already had a job, and they could know the specific requirements for being employed. Taking into account the specificity of the graduate students being often on part-time work or competitions and training, therefore being often on individual education schedule, the students were offered an eight-hour blended course with some distance online assignments and tests for a month.

\subsection{Materials}

The description of the online course elements is provided below.

\subsubsection{Course description}

Taking into account the main characteristics of the academic work, which make the course employability oriented, we tried to include the elements for developing communication, collaboration, creative and critical thinking, reflection, and arising the selfcharacteristics. Thus, at the beginning of each unit, the tasks are aimed at engaging the students into a specific professional topic of their interest and increasing their motivation. The direct questions of this speaking task are designed to awaken personal involvement and critical thinking.

The professional constituent of the course was developed specifically for the specialism of the students, so the sports students study sports and training professional content, and the finance students study the professional content related to their specificity. The element of personalization makes the tasks close to students, getting them involved in the topic. The features of the communication element are used in the tasks to make professional situations appropriate for real-life and specific needs. The design of the online course is difficult: 
much speaking yet writing as another productive skill is amply used in the tasks. Writing is integrated with authentic situations in listening in forms of short videos, and the assignments are made to apply critical thinking and reflective practice. We tried to blend collaboration as well. The course has the tasks to evaluate other students' work and to discuss a point in blog activities and on the Padlet platform. The tasks also require reflective practice in the responses.

\subsection{Data Collection}

The questionnaire on the Google Form had the aim to assess the online tasks given to the graduate students to define whether the training had the component for raising employability. The questionnaire contained the positions designed to find particular employability characteristics. The students were asked to rate the questions from 1 to 5 where 5 is the highest rank of the statement relating to them.

1. This course is relevant to my professional goals.

2. Overall course was practical and useful for my job

3. The lexis used in the course was relevant to the specificity of my profession.

4. The texts were relevant to authentic professional situations.

5. The course contained videos from real professional situations.

6. The tasks made me think and reflect.

7. I had to use my imagination to do the tasks related to my job.

8. The course gave me the possibility to organize my learning process correctly.

9. I often had opportunities for a personal response.

10. I did my best in the process of learning.

11. I had enough possibility to communicate with my peers.

12. I had enough of writing tasks.

13. This course was not technically difficult.

14. The course had the necessary components for developing thinking skills.

15. The course raised my self-organizing skills.

16. The course developed practical professional communication.

The general criteria for evaluating employability we defined were:

1. professional component (Questions 1-5);

2. critical thinking and reflection development (Questions 6-7, 14);

3. self-directedness and self-organizational skills (Questions 8-10, 15);

4. ability for collaboration (Question 11, 16);

5. other relevant Media skills, like Writing and IT literacy (Questions 12-13).

Data for the main study was collected after a week after completing the course. The survey was conducted anonymously. There were 30 answers registered.

\section{RESULTS}

The data collected from the survey revealed the following. The items were labeled ranging according to the Likert scale from 1 to 5 , where 1 relates to the initial level and is the lowest one, and 5 is the highest - and refers to 'excellent'. In order to conduct further analysis of this survey, we applied descriptive statistics and effect size measurement (Table 1). 
Table 1 Summary descriptive statistics of the variables

\begin{tabular}{|c|l|l|l|l|l|}
\hline \multirow{2}{*}{$№$} & \multicolumn{1}{|c|}{ Variable } & Mean & $\begin{array}{c}\text { Std. } \\
\text { Dev }\end{array}$ & Min & Max \\
\hline 1 & This course is relevant to my professional goals & 4.43 & 0.82 & 2 & 5 \\
\hline 2 & I did my best in the process of learning & 4.07 & 0.87 & 3 & 5 \\
\hline 3 & I had enough of writing tasks & 4.7 & 0.53 & 3 & 5 \\
\hline 4 & I had enough possibility to communicate with my peers & 4.27 & 0.83 & 3 & 5 \\
\hline 5 & The tasks made me think and reflect & 4.67 & 0.55 & 3 & 5 \\
\hline 6 & I often had opportunities for a personal response & 4.23 & 0.82 & 3 & 5 \\
\hline 7 & The texts were relevant to authentic professional situations & 4.8 & 0.41 & 4 & 5 \\
\hline 8 & $\begin{array}{l}\text { The lexis used in the course was relevant to the specificity of } \\
\text { my profession }\end{array}$ & 4.37 & 0.72 & 3 & 5 \\
\hline 9 & The course contained videos from real professional situations & 4.83 & 0.38 & 4 & 5 \\
\hline 10 & $\begin{array}{l}\text { The course gave me the possibility to organize my learning } \\
\text { process correctly }\end{array}$ & 4.63 & 0.56 & 3 & 5 \\
\hline 11 & This course was not technically challenging. & 4.73 & 0.53 & 3 & 5 \\
\hline 12 & I had to use my imagination to do the tasks related to my job & 4.57 & 0.63 & 3 & 5 \\
\hline 13 & Overall course was practical and useful for my job. & 4.87 & 0.35 & 4 & 5 \\
\hline 14 & $\begin{array}{l}\text { The course had the necessary components for developing } \\
\text { thinking skills }\end{array}$ & 4.77 & 0.43 & 4 & 5 \\
\hline 15 & The course raised my self-organizing skills & 4.57 & 0.63 & 3 & 5 \\
\hline 16 & The course developed practical professional communication & 4.67 & 0.48 & 4 & 5 \\
\hline
\end{tabular}

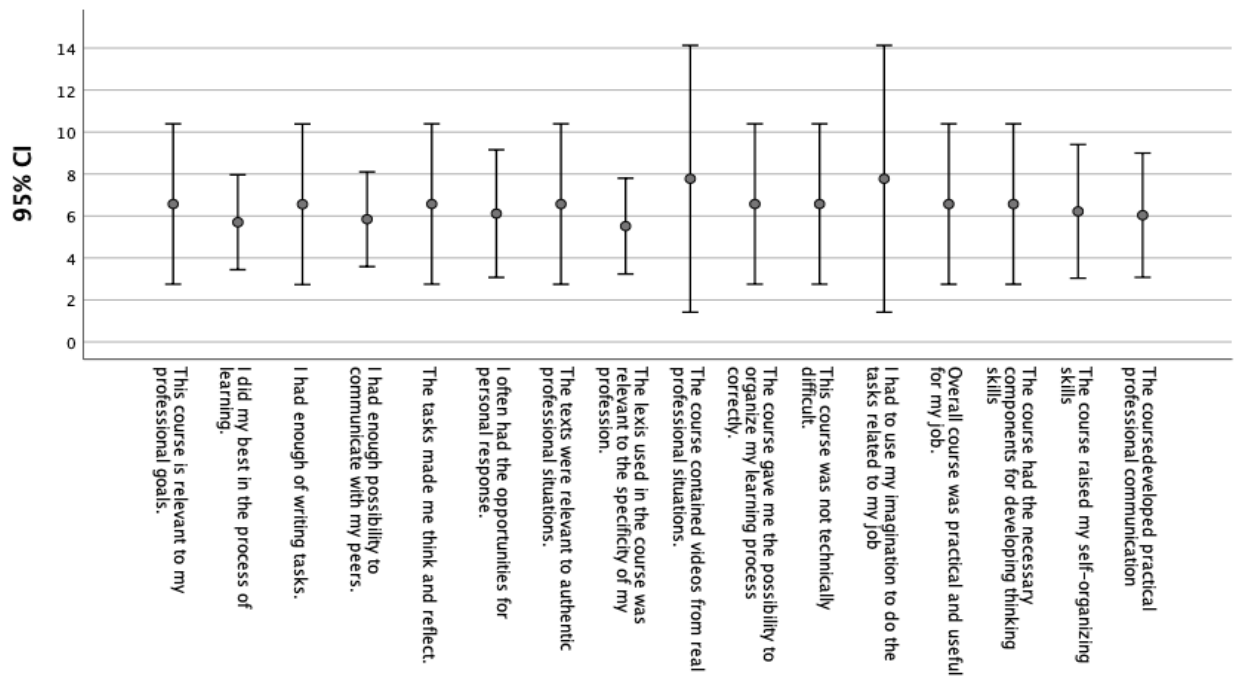

Distribution of the variables 
The results show that the highest meaning relates to the professional and critical thinking aspects where the respondents processed the statements related to professional content and thinking skills, as well as the characteristics of the easily operated course from the technical point of view.

To prove the questionnaire results statistically, we first needed to check the assumptions of ANOVA. Our observations are independent - either selection or assignment in the experiment was random. The graduate students at Sumy State University have the same curriculum and the conventions in the study process. Then, the response variable is normally distributed, proving the normality of the test. The histograms of the main factors in our research look acceptable, which proves normal distribution.

As we have chosen The task made me think and reflect as a factor - explanatory variable to the response variables: This course is relevant to my professional goals, The texts were relevant to authentic professional situations, Overall course was practical and useful for my job and I had to use my imagination to do the tasks related to my job, we checked the normality of distribution of these variables and presented them in the histograms.

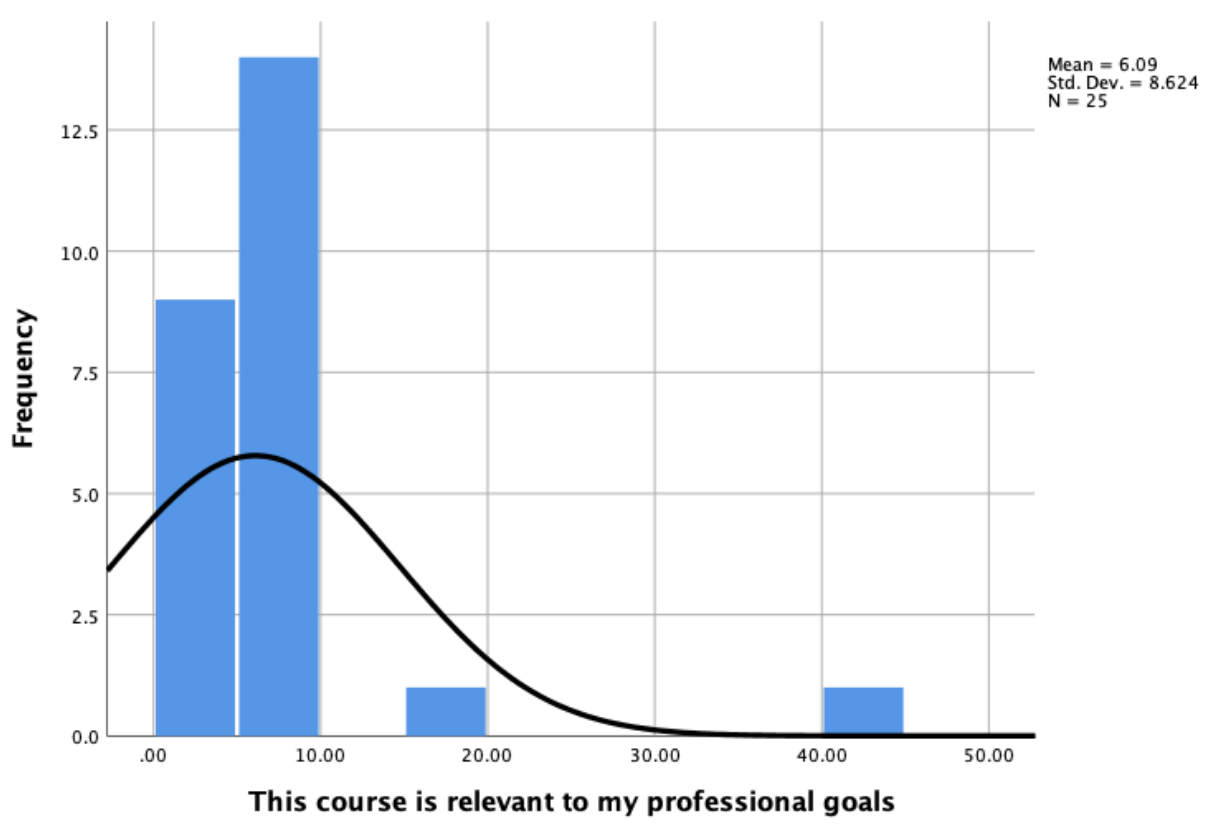



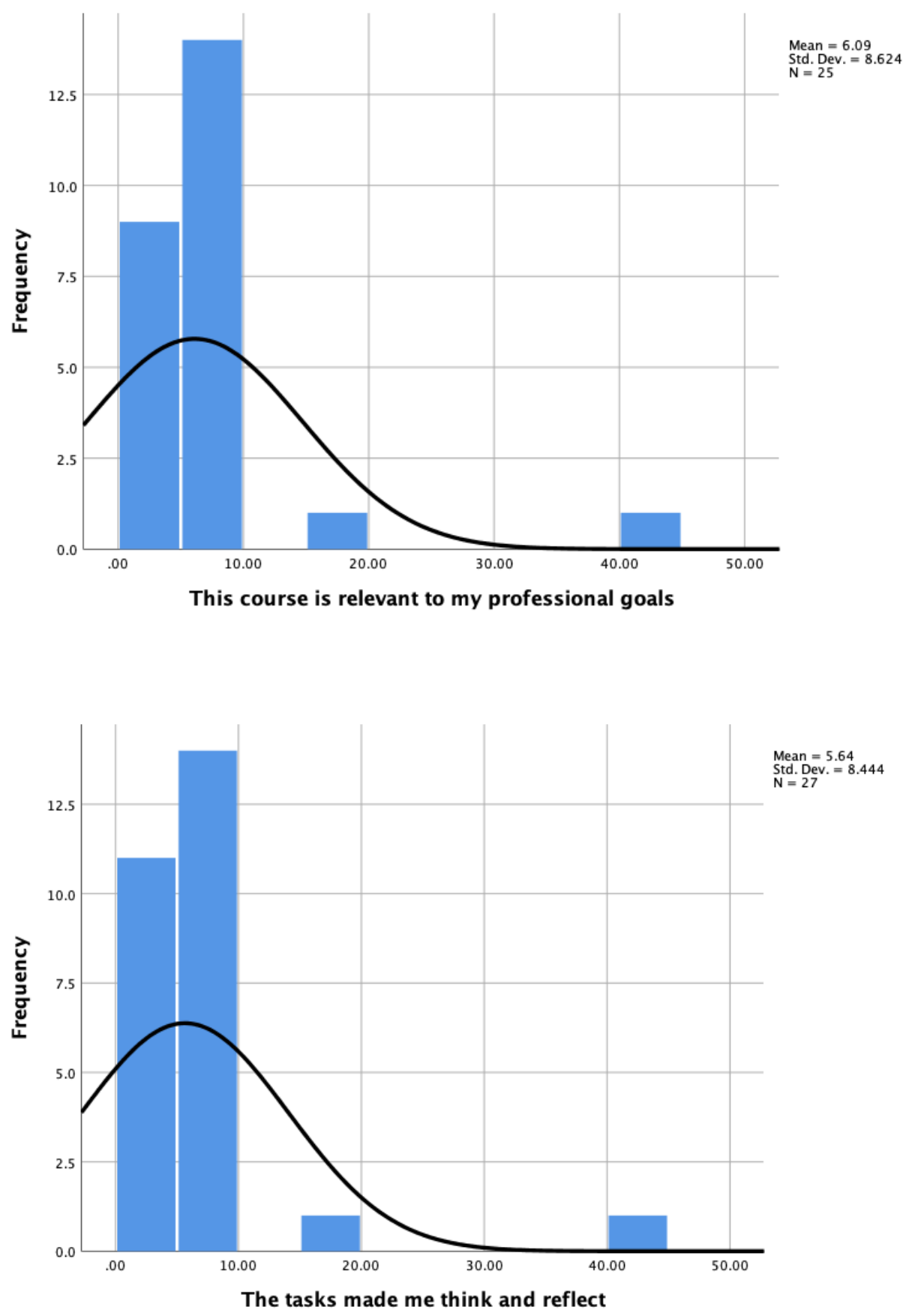

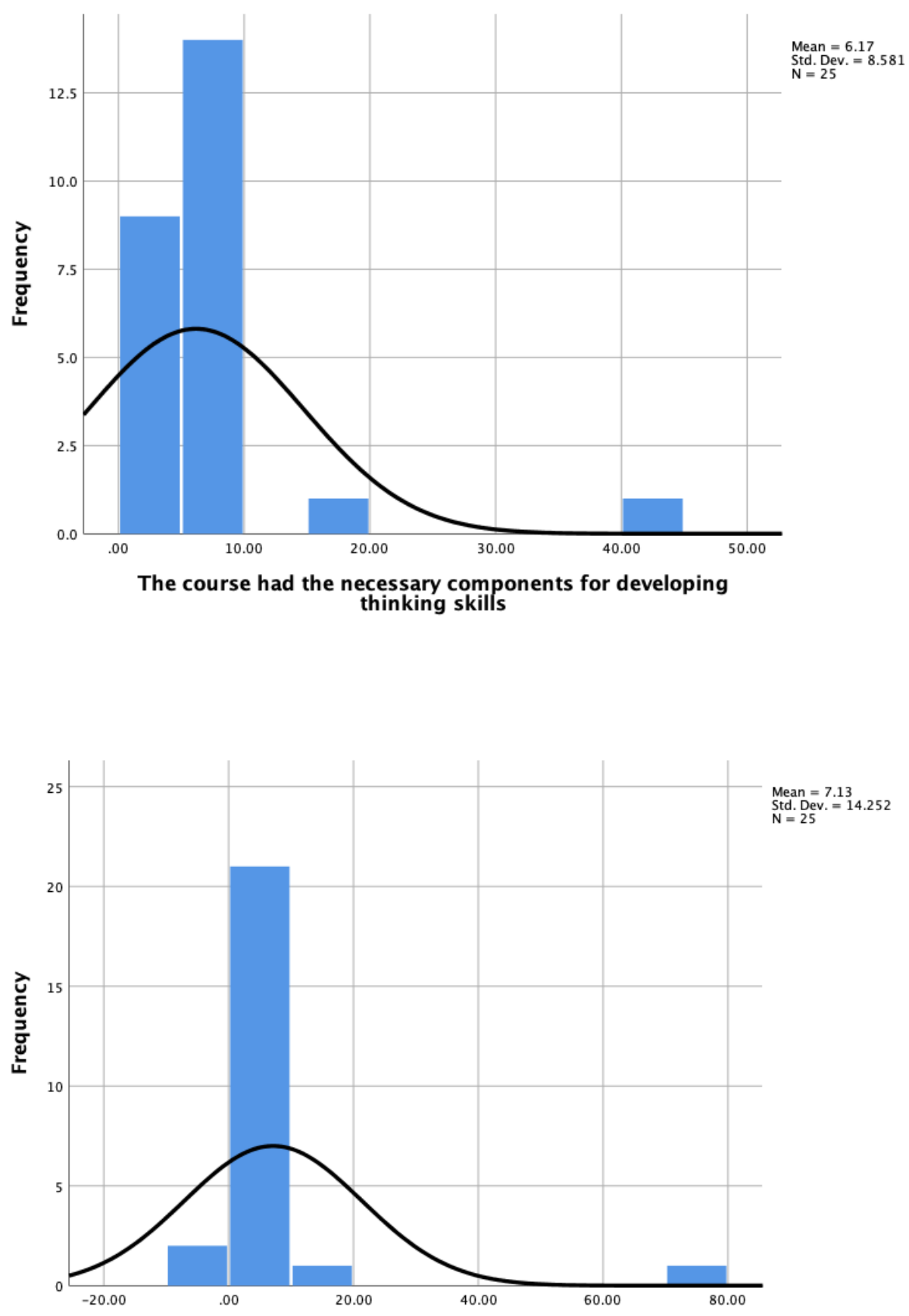

I had to use my imagination to do the tasks related to my job 


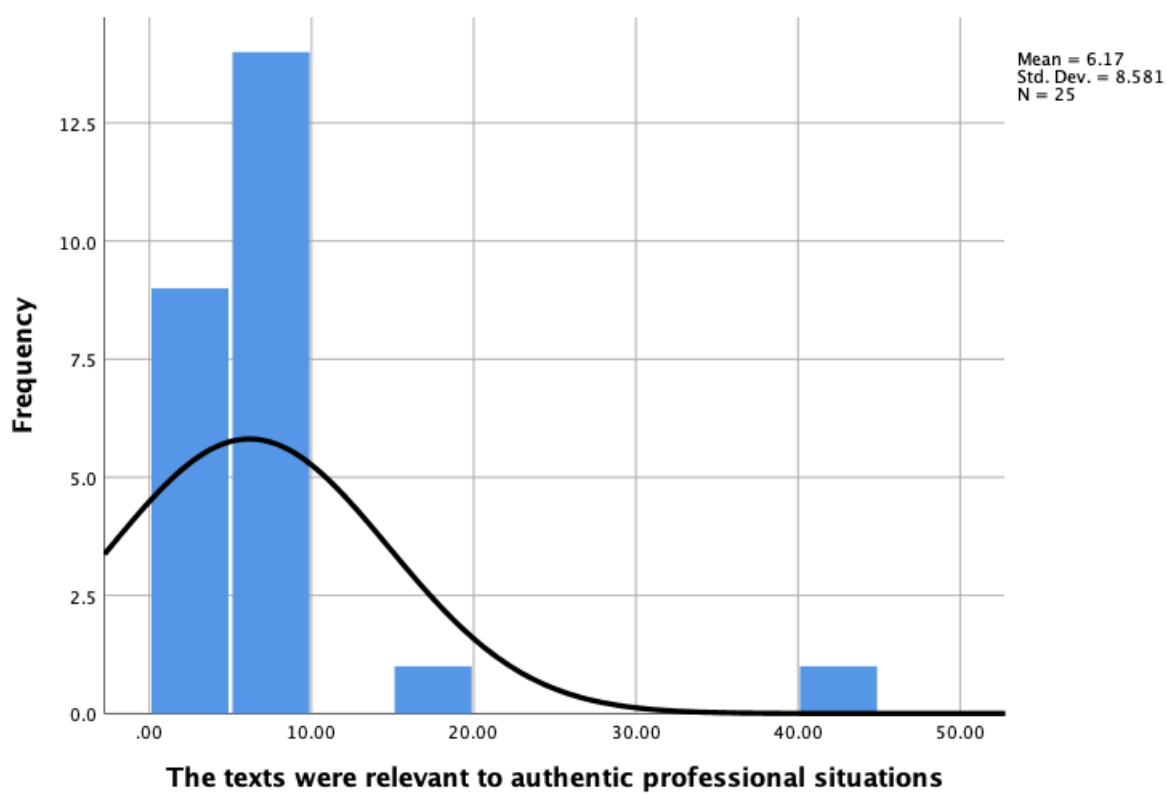

Another assumption we met was the homogeneity of variances. The means of the samples are approximately the same. Moreover, in each group, we have more than ten observations. We made computations in the statistics software and found an F-value statistic test with the within-group and between-group variances. The results of the F-value are shown in Table 2 with the degrees of freedom for each factor. The software provides an exact p-value of 0.00 . We can reject the null hypothesis and conclude that at least one of the professional competency groups differs from the others in terms of mean critical thinking.

Table 2 ANOVA results on the factors

\begin{tabular}{|c|c|c|c|c|c|c|}
\hline & & $\begin{array}{l}\text { Sum of } \\
\text { Squares }\end{array}$ & $\mathrm{df}$ & $\begin{array}{l}\text { Mean } \\
\text { Square }\end{array}$ & $\mathrm{F}$ & Sig. \\
\hline \multirow{3}{*}{$\begin{array}{l}\text { Overall course was practical } \\
\text { and useful for my job }\end{array}$} & Between groups & 1767.45 & 10 & 176.75 & 1048.94 & 0.000 \\
\hline & Within groups & 2.36 & 14 & 0.17 & & \\
\hline & Total & 1769.81 & 24 & & & \\
\hline \multirow{3}{*}{$\begin{array}{l}\text { This course is relevant to my } \\
\text { professional goals }\end{array}$} & Between groups & 1782.5 & 10 & 178.25 & 1057.88 & 0.000 \\
\hline & Within groups & 2.3 & 14 & 0.17 & & \\
\hline & Total & 1784.8 & 24 & & & \\
\hline \multirow{3}{*}{$\begin{array}{l}\text { I had to use my imagination to } \\
\text { do the tasks related to my job }\end{array}$} & Between groups & 4873.75 & 10 & 487.38 & 7391.86 & 0.000 \\
\hline & Within groups & 0.92 & 14 & 0.07 & & \\
\hline & Total & 4874.68 & 24 & & & \\
\hline \multirow{3}{*}{$\begin{array}{l}\text { The texts were relevant to } \\
\text { authentic professional } \\
\text { situations }\end{array}$} & Between groups & 1764.7 & 10 & 176.47 & 1047.32 & 0.000 \\
\hline & Within groups & 2.36 & 14 & 0.17 & & \\
\hline & Total & 1767.07 & 24 & & & \\
\hline \multirow{3}{*}{$\begin{array}{l}\text { The course had the necessary } \\
\text { components for developing } \\
\text { thinking skills }\end{array}$} & Between groups & 1764.71 & 10 & 176.47 & 1047.32 & 0.000 \\
\hline & Within groups & 2.36 & 14 & 0.17 & & \\
\hline & Total & 1767.07 & 24 & & & \\
\hline
\end{tabular}


Further on, we tried to check the correlation between these variables to answer the research question about the individual relation between them. At this stage, we applied Pearson's correlation analysis to check strength and direction of association that exists between our target set of variables ("This course is relevant to my professional goals," "The texts were relevant to authentic professional situations," "I had to use my imagination to do the tasks related to my job," "The course had the necessary components for developing thinking skills," "Overall course was practical and useful for my job" and "The tasks made me think and reflect" (Table 3).

Table 3 Pearson's correlation analysis

\begin{tabular}{|c|c|c|c|c|c|c|c|}
\hline & & $\begin{array}{c}\text { This course } \\
\text { is relevant } \\
\text { to my } \\
\text { professional } \\
\text { goals }\end{array}$ & $\begin{array}{c}\text { The tasks } \\
\text { made me } \\
\text { think and } \\
\text { reflect }\end{array}$ & $\begin{array}{c}\text { The texts } \\
\text { were } \\
\text { relevant to } \\
\text { authentic } \\
\text { professional } \\
\text { situations }\end{array}$ & $\begin{array}{c}\text { I had to use } \\
\text { my } \\
\text { imagination } \\
\text { to do the } \\
\text { tasks } \\
\text { related to } \\
\text { my job }\end{array}$ & \begin{tabular}{|c|} 
Overall \\
course \\
was \\
practical \\
and useful \\
for my job
\end{tabular} & $\begin{array}{l}\text { The course } \\
\text { had the } \\
\text { necessary } \\
\text { components } \\
\text { for } \\
\text { developing } \\
\text { thinking } \\
\text { skills }\end{array}$ \\
\hline \multirow{5}{*}{$\begin{array}{l}\text { This course is } \\
\text { relevant to my } \\
\text { professional } \\
\text { goals }\end{array}$} & $\begin{array}{c}\text { Pearson } \\
\text { Correlation }\end{array}$ & 1 & $0.999 * *$ & $0.999 * *$ & $0.987 * *$ & $1.000 * *$ & $0.999 * *$ \\
\hline & Sig. (2-tailed) & & 0.000 & 0.000 & 0.000 & 0.000 & 0.000 \\
\hline & $\begin{array}{c}\begin{array}{c}\text { Sum of Squares } \\
\text { and Cross-products }\end{array} \\
\end{array}$ & 1784.87 & 1784.98 & 1774.61 & 2911.86 & 1776.4 & 1773.61 \\
\hline & Covariance & 74.37 & 74.37 & 73.94 & 121.33 & 74.02 & 73.9 \\
\hline & $\mathrm{N}$ & 25 & 25 & 25 & 25 & 25 & 25 \\
\hline \multirow{5}{*}{$\begin{array}{l}\text { The tasks } \\
\text { made me think } \\
\text { and reflect }\end{array}$} & $\begin{array}{c}\text { Pearson } \\
\text { Correlation }\end{array}$ & $0.999 * *$ & 1 & $0.998 * *$ & $0.987 * *$ & $0.998 * *$ & $0.998 * *$ \\
\hline & Sig. (2-tailed) & 0.000 & & 0.000 & 0.000 & 0.000 & 0.000 \\
\hline & $\begin{array}{c}\text { Sum of Squares } \\
\text { and Cross-products }\end{array}$ & 1784.98 & 1853.87 & 1774.2 & 2913.89 & 1776.12 & 1774.2 \\
\hline & \begin{tabular}{|l|} 
Covariance \\
\end{tabular} & 74.37 & 71.3 & 73.93 & 121.41 & 74.01 & 73.93 \\
\hline & $\mathrm{N}$ & 25 & 27 & 25 & 25 & 25 & 25 \\
\hline \multirow{5}{*}{$\begin{array}{l}\text { The texts were } \\
\text { relevant to } \\
\text { authentic } \\
\text { professional } \\
\text { situations }\end{array}$} & $\begin{array}{c}\text { Pearson } \\
\text { Correlation }\end{array}$ & $0.999 * *$ & $0.998 * *$ & 1 & $0.987 * *$ & $1.000 * *$ & $0.999 * *$ \\
\hline & Sig. (2-tailed) & 0.000 & 0.000 & & 0.000 & 0.000 & 0.000 \\
\hline & \begin{tabular}{|c|} 
Sum of Squares \\
and Cross-products
\end{tabular} & 1774.61 & 1774.2 & 1767.07 & 2897.13 & 1768.39 & 1766.07 \\
\hline & Covariance & 73.94 & 73.93 & 73.63 & 120.71 & 73.68 & 73.5 \\
\hline & $\mathrm{N}$ & 25 & 25 & 25 & 25 & 25 & 25 \\
\hline \multirow{5}{*}{$\begin{array}{l}\text { I had to use } \\
\text { my } \\
\text { imagination to } \\
\text { do the tasks } \\
\text { related to my } \\
\text { job }\end{array}$} & $\begin{array}{c}\text { Pearson } \\
\text { Correlation }\end{array}$ & $0.987 * *$ & $0.987 * *$ & $0.987 * *$ & 1 & $0.987 * *$ & $0.987 * *$ \\
\hline & Sig. (2-tailed) & 0.000 & 0.000 & 0.000 & & 0.000 & 0.000 \\
\hline & $\begin{array}{c}\text { Sum of Squares } \\
\text { and Cross-products }\end{array}$ & 2911.88 & 2913.89 & 2897.13 & 4874.68 & 2899.77 & 2896.13 \\
\hline & Covariance & 121.33 & 121.41 & 120.71 & 203.11 & 120.82 & 120.67 \\
\hline & $\mathrm{N}$ & 25 & 25 & 25 & 25 & 25 & 25 \\
\hline \multirow{2}{*}{$\begin{array}{l}\text { Overall course } \\
\text { was practical }\end{array}$} & $\begin{array}{c}\text { Pearson } \\
\text { Correlation }\end{array}$ & $1.000 * *$ & $0.998 * *$ & $1.000 * *$ & $0.987 * *$ & 1 & $0.999 * *$ \\
\hline & Sig. (2-tailed) & 0.000 & 0.000 & 0.000 & 0.000 & & 0.000 \\
\hline
\end{tabular}




\begin{tabular}{|c|c|c|c|c|c|c|c|}
\hline \multirow[t]{3}{*}{$\begin{array}{l}\text { and useful for } \\
\text { my job }\end{array}$} & $\begin{array}{c}\text { Sum of Squares } \\
\text { and Cross-products }\end{array}$ & 1776.44 & 1776.12 & 1768.39 & 2899.77 & 1769.81 & 1767.39 \\
\hline & Covariance & 74.02 & 74.02 & 73.69 & 120.82 & 73.74 & 73.64 \\
\hline & $\mathrm{N}$ & 25 & 25 & 25 & 25 & 25 & 25 \\
\hline \multirow{5}{*}{$\begin{array}{l}\text { The course } \\
\text { had the } \\
\text { necessary } \\
\text { components } \\
\text { for developing } \\
\text { thinking skills }\end{array}$} & $\begin{array}{c}\text { Pearson } \\
\text { Correlation } \\
\end{array}$ & $0.999 * *$ & $0.998 * *$ & $0.999 * *$ & $0.987 * *$ & $0.999 * *$ & 1 \\
\hline & Sig. (2-tailed) & 0.000 & 0.000 & 0.000 & 0.000 & 0.000 & \\
\hline & $\begin{array}{c}\text { Sum of Squares } \\
\text { and Cross-products }\end{array}$ & 1773.61 & 1774.2 & 1766.07 & 2896.13 & 1767.39 & 1767.07 \\
\hline & Covariance & 73.9 & 73.93 & 73.59 & 120.67 & 73.64 & 73.63 \\
\hline & $\mathrm{N}$ & 25 & 25 & 25 & 25 & 25 & 25 \\
\hline
\end{tabular}

The results presented in Table 3 show the strong correlation in all factors we have chosen with the significant meaning in correlation between each other.

We checked the partial correlation between the variables and found a significant positive correlation (Table 4).

Table 4 Partial Correlation Analysis

\begin{tabular}{|c|c|c|c|c|c|}
\hline \multicolumn{3}{|c|}{ Control Variables } & \begin{tabular}{|c|} 
This course is \\
relevant to \\
my \\
professional \\
goals \\
\end{tabular} & \begin{tabular}{|c|} 
Overall \\
course was \\
practical \\
and useful \\
for my job \\
\end{tabular} & \begin{tabular}{|c|} 
The texts \\
were relevant \\
to authentic \\
professional \\
situations \\
\end{tabular} \\
\hline \multirow{3}{*}{$\begin{array}{l}\text { The tasks made me } \\
\text { think and reflect \& } \\
\text { I had to use my } \\
\text { imagination to do } \\
\text { the tasks related to } \\
\text { my job \& The } \\
\text { course had the } \\
\text { necessary } \\
\text { components for } \\
\text { developing thinking } \\
\text { skills }\end{array}$} & $\begin{array}{l}\text { This course is } \\
\text { relevant to my } \\
\text { professional goals }\end{array}$ & Correlation & 1.000 & 0.79 & 0.68 \\
\hline & $\begin{array}{c}\text { Overall course was } \\
\text { practical and useful } \\
\text { for my job }\end{array}$ & Correlation & 0.79 & 1.000 & 0.99 \\
\hline & $\begin{array}{l}\text { The texts were } \\
\text { relevant to } \\
\text { authentic } \\
\text { professional } \\
\text { situations }\end{array}$ & Correlation & 0.68 & 0.99 & 1.000 \\
\hline
\end{tabular}

The correlation between critical thinking and professional components is appeared to be strong positive $0.791,0.684$, and 0.987 , which proved our hypothesis about congruency between these constituents. 


\section{DISCUSSION}

This study investigated the potential role of critical thinking in influencing the development of employability qualities in graduate students. The important contribution of this study lies in applying critical thinking tasks in the ESP online course. The statistic test proved the grounded theory about correlation between the factors we have chosen for our research: critical thinking is congruent with professional competence, consequently, increases employability of the graduate students at Sumy State University. The positive connection between these factors shows the constant growth of the researched qualities, which enables them to be developed in this combination.

Our findings are congruent with the arguments laid out in the recent research about the mutual relationship between the professional competency and the critical thinking tasks (Lowden et al. 2011; Deeley 2014). The results of this study also support the argument that employability is influenced by self-awareness and self-organization (Qenani et al. 2014; Lim et al. 2011). In our study, the correlation between self-organization and professional factor is not the highest, yet it is expressed by moderate positive growth.

However, our findings indicate that the factor of communication is not significantly expressed in online education. Although the students could complete the written tasks related to communication and relation to their peers, they considered this type of communication not as real, which is expressed in face-to-face professional communication and collaboration. Another reason for this is that this course was a pilot project and it might have had some instructional and design faults which will definitely be taken into account for the next course.

\section{CONCLUSION}

Today the increasing demand for self-aware professionals with developed critical thinking and problem-solving skills is a clear need in the employability sector in all spheres of our community life (McQuaid et al. 2005; Lowden et al., 2011). To meet the demand of the employers, educators need to understand the significance of including the components of professional learning, which aim the professional factor essential for successful employability. The results of this study define the main features of employability in online training, which enable teachers to pay more attention to crucial factors. In this study, the development of critical thinking was the essential factor in determining the professional skills necessary for employability. The other relevant important variables which were argued in the study were collaboration and self-organization.

The design of the research presents one of the limitations of the study. The online course may lessen the development of critical professional qualities as it has a wide range of possibilities for written communication. However, it may have just a model of live professional communication. The other limitation is the number of students in this study. The research may have a higher degree of validity with the larger sample. Besides, not all possible factors which have a direct impact on professional development were measured in this research.

Moreover, the personal interpretation of the questions in the questionnaire might be various depending on the students' aims. Future work should examine other potential factors that might influence the employability sphere. In particular, the relationship between the design of online courses with more advanced functions and self-organization as a means of motivation growth for developing professionally. 


\section{REFERENCES}

Andrews, Jane, and Helen Higson. 2008. "Graduate Employability, 'soft skills' versus 'Hard' Business Knowledge: A European Study." Higher Education in Europe 33 (4): 411-22.

Botha, Jo-Anne, Melinde Coetzee, and Mariette Coetzee. 2015. "Exploring Adult Learners' Self-Directedness in Relation to Their Employability Attributes in Open Distance Learning." Journal of Psychology in Africa 25 (1). Informa UK Limited: 65-72.

Butcher, John, and John Rose-Adams. 2015. "Part-Time Learners in Open and Distance Learning: Revisiting the Critical Importance of Choice, Flexibility and Employability." Open Learning 30 (2). Routledge: 127-37.

De Vos, Ans, Sara De Hauw, and Beatrice I.J.M. Van der Heijden. 2011. "Competency Development and Career Success: The Mediating Role of Employability." Journal of Vocational Behavior 79 (2): 438-47.

Deeley, Susan J. 2014. "Summative Co-Assessment: A Deep Learning Approach to Enhancing Employability Skills and Attributes." Active Learning in Higher Education 15 (1): 39-51.

Ehiyazaryan, Ester. 2009. "Enhancing Employability: Integrating Real World Experience in the Curriculum." Education and Training 51 (4): 292-308.

Fallows, Stephen, and Christine Steven. 2000. "Building Employability Skills into the Higher Education Curriculum: A University-Wide Initiative." Education + training.

Franz, Jill. 2008. "A Pedagogical Model of Higher Education / Industry Engagement for Enhancing Employability and Professional Practice." Proceedings Work Integrated Learning (WIL): Transforming Futures, Practice...Pedagogy ...Partnerships 2008: 164-69.

Glass, Gene, and Kenneth Hopkins. "Statistical methods in education and psychology." Psyccritiques 41.12 (1996).

Harvey, Lee. 2001. "Defining and Measuring Employability." Quality in Higher Education 7 (2): $97-109$.

Liashenko, Iryna, and Lyudmyla Hnapovska. 2019. "Blended Education: Patterns of Implementation at Sumy State University." Revista Romaneasca Pentru Educatie Multidimensionala 11 (3). Asociatia LUMEN: 141-62.

Liashenko, Iryna. 2019. "Students Perceptions of ESP Course for Cynological Translators." Journal of Teaching English for Specific and Academic Purposes 7.1 (2019): 017-030.

Lim, Tina, Mansor Fadzil, Latifah Abdol Latif, T Goolamally, Norlia, and Norziati Mansor. 2011. "Producing Graduates Who Meet Employer Expectations: Open and Distance Learning Is a Viable Option." The International Lifelong Learning Conference 2011, 374-88.

Lowden, K., S. Hall, D. Elliot, and Lewin, 2011. "Employers' perceptions of the employability skills of new graduates". London: Edge Foundation.

McQuaid, C. D., J. R. Lindsay, and Griffith. 2005. "Interacting Effects of Wave Exposure, Tidal Height and Substratum on Spatial Variation in Densities of Mussel Perna Perna Plantigrades.” Marine Ecology Progress Series 301 (October). Inter-Research: 173-84.

Nenzhelele, Tshilidzi Eric. 2014. "Employability through Experiential Learning Course in Open Distance Learning Institution." Mediterranean Journal of Social Sciences 5 (20). Mediterranean Center of Social and Educational Research: 1602-12. 
Overtoom, Christine. Employability skills: An update. ERIC Clearinghouse, 2000.

Pool, Lorraine Dacre, and Peter Sewell. 2007. "The Key to Employability: Developing a Practical Model of Graduate Employability." Education and Training 49 (4): 277-89.

Qenani, Eivis, Neal MacDougall, and Carol Sexton. 2014. "An Empirical Study of SelfPerceived Employability: Improving the Prospects for Student Employment Success in an Uncertain Environment." Active Learning in Higher Education 15 (3). SAGE Publications Ltd: 199-213.

Rebenko, Maryna, Oksana Nikolenko, and Victor Rebenko. "Listening Comprehension Proficiency Development of Information Technology Students in ESP classroom." International Journal of Learning, Teaching, and Educational Research 18.11 (2019): 245-264.

Smith, Vicki. 2010. "Review Article: Enhancing Employability: Human, Cultural, and Social Capital in an Era of Turbulent Unpredictability." Human Relations.

Tymon, Alex. 2013. "The Student Perspective on Employability." Studies in Higher Education 38 (6): 841-56.

Wuensch, Karl L., and James D. Evans. 1996. "Straightforward Statistics for the Behavioral Sciences." Journal of the American Statistical Association 91 (436). JSTOR: 1750. 